УДК 528.563

DOI: https://doi.org/10.26642/ten-2020-1(85)-158-164

.М. Безвесільна, Д.т.н., проф.

Національний технічний університет

«Київький політехнічний інститут ім. Ігоря Сікорського»

А.Г. Ткачук, к.т.н., доц.

А.А. Гуменюк, к.т.н., доц.

В.М. Янчук, к.т.н., доц.

О.О. Добржанський, к.т.н., доц.

Державний університет «Житомирська політехніка»

\title{
Використання методу двоканальності для підвищення точності нового п’єзоелектричного чутливого елемента системи стабілізації озбросння
}

\begin{abstract}
У статті розглянуто будову та принциип роботи системи стабілізації озброєння, яка технічно являє собою набір датчиків $і$ обчислювальний комплекс, щзо з'єднаний з приводом гармати. Система стабілізацї забезпечує сталість кутів між осями нерухомої системи координат і осями, жорстко зв'язаними з об'єктом стабілізації. Встановлено, щчо якість функиіонування систем стабілізації озброєння, як в режимі стабілізації, так $i$ в режимі наведення, оиінюється вказаними далі показниками: стійкість, точність стабілізації зброї, якість стабілізації, швидкість наведення і характер розподілу по куту повороту пульта управління, час готовності стабілізатора, час безперервної роботи стабілізатора, надійність функціонування та характер $і$ час перехідних прочесів при відпрацюванні кутів неузгодженості. Точність стабілізації є основним показником, щзо характеризує роботу системи управління вогнем у режимі стабілізації. Зовнішні збурення, обумовлені безперервними випадковими коливаннями корпусу рухомою легкою броньованою технікою, викликають відхилення стабілізованого озброєння від заданого напрямку наведення. Розглянуто новий п'єзоелектричний чутливий елемент системи стабілізаџії озброєння та доиільність використання методу двоканальності для підвищення його точності. Встановлено, щзо завдяки використанню додатково введеного у конструкцію чутливого п'єзоелектричного елемента другого каналу вимірювання забезпечується відсутність у його вихідному сигналі похибок від впливу вертикального прискорення, від залишкової неідентичності конструкцій однакових n'єзоелектричних пластин та мас, від впливу зміни температури, вологості та тиску зовнішнього середовища (тобто інструментальних похибок), які можуть бути значними.
\end{abstract}

Ключові слова: n'єзоелектричний чутливий елемент; точність; похибка; двоканальність.

Актуальність теми. Системи стабілізації різних видів застосовуються сьогодні у навігаційних пристроях і системах управління кораблів, літальних апаратів, автомобілів, а також у системах орієнтації антен, телескопів та інших приладів, що встановлені на рухомих об'єктах. У зв'язку з тим, що необхідна точність подібних пристроїв безперервно підвищується, ростуть і вимоги щодо точності, які ставляться до комплексів стабілізації.

Стабілізатор озброєння легкої броньованої техніки являє собою набір датчиків і обчислювальний комплекс, що з'єднаний з приводом гармати. На основі показників датчиків визначаються параметри переміщення платформи та надходять керуючі команди приводу гармати, який компенсує відхилення $[1,2]$.

Системи стабілізації, які існують сьогодні, не можуть достатньо ефективно виконувати поставлені перед ними завдання. Досвідом воєнних конфліктів свідчить, що найбільша частина втрат парку броньових машин $є$ наслідком використання малоефективних систем стабілізації озброєння. Тому забезпечення покращення експлуатаційних характеристик комплексу стабілізації озброєння є актуальним.

Аналіз останніх досліджень та публікацій. Досягнення високої точності комплексів стабілізації (КС) стало можливим сьогодні завдяки досить високій якості сучасних елементів гіроскопічної техніки та значного розвитку теорії гіроскопічних пристроїв працями найвизначніших вчених-математиків i механіків: А.Н. Крилова, Б.В. Булгакова, О.Ю. Ішлінського, Я.М. Ройтенберга, С.С. Рівкіна, В.А. Павлова, Е.Г. Попова, А.І. Лур'є, В.В. Солодовнікова та інших. Провідну роль відіграють і досягнення у галузі інерціальних систем навігації (IHC) та чутливих елементів ІНС, що висвітлені у наукових працях школи видатних вчених НТУУ «КПІ ім. Ігоря Сікорського»: А.А. Одинцова, М.А. Павловського, О.В. Збруцького, Б.Б. Самотокіна, В.В. Карачуна, Л.М. Рижкова та інших. Питання метрології, що корисні під час досліджень похибок чутливих елементів комплексів стабілізації, широко висвітлені у роботах В.П. Кваснікова, Л.В. Коломійця, В.П. Короткова, П.В. Новицького, Р.В. Бичківського та інших. 
У [3] побудовано схемотехнічні моделі та проведено моделювання п’єзоелектричних одноканальних перетворювачів з додатковими електричними коливальними контурами, які можуть бути використані як чутливий елемент стабілізатора озброєння. Використання таких моделей дозволяє за допомогою прикладних програм оцінювати характеристики та прогнозування параметрів $\mathrm{i}$ режимів роботи п’єзоелектричних перетворювачів. Проте отримані результати не можуть бути використані як доказ того, що датчик такої конструкції має вищу точність від аналогів, оскільки не розглянуто двоканальні схеми компенсації похибок вимірювання.

У [4] виконано синтез нейромережевої системи наведення і стабілізації озброєння легкої броньованої техніки. Розроблено структурну схему системи, компонентами якої є пропорційно-диференціальний регулятор положення i нейромережевий регулятор швидкості. Виконано синтез нейрорегулятора 3 прогнозуванням. Однак не розглянуто доцільність використання нейромережевого підходу для компенсації інструментальних похибок.

У [5-9] запропоновано як чутливий елемент системи стабілізації використовувати коріолісовий вібраційний гіроскоп. Проаналізовано склад і принцип роботи відомої системи ударо- і віброзахисту навігаційного комплексу легкої броньованої техніки. Однак відсутні пропозиції щодо покращення технічних характеристик системи, аналізу математичної моделі та похибок чутливих елементів системи.

У [10, 11] розглянуто систему стабілізації 3 оптичним гіроскопом та приведено основні конструкційні розрахунки. Запропоновано програмні методи фільтрації вихідних сигналів акселерометрів та гравіметрів. Відсутнє порівняння із відомими аналогами.

У [12] описано новий мобільний прилад для вимірювання динамічного вектора прискорення сили тяжіння і його градієнтів у підводному середовищі. Цей датчик може встановлюватися на озброєнні військових підводних човнів. Отримані результати досліджень можна використовувати й у проєктуванні системи стабілізації озброєння легких броньованих машин, проте необхідно враховувати особливості наземної експлуатації системи.

Метою статті $є$ дослідження доцільності використання методу двоканальності для підвищення точності нового п’єзоелектричного чутливого елемента системи стабілізації озброєння.

Викладення основного матеріалу. Як система стабілізації у статті розглядається система автоматичного регулювання, що забезпечує збереження певної кутової орієнтації башти, на якій встановлено озброєння, відносно системи координат, осі якої певним чином орієнтовані у просторі. Ця система координат $€$ опорною або нерухомою. Залежно від конкретного завдання це може бути, наприклад, інерціальна система координат або система, осі якої спрямовані по вертикалі до місця знаходження башти.

Система стабілізації забезпечує сталість кутів між осями нерухомої системи координат і осями, що жорстко зв'язані 3 об'єктом стабілізації, який у подальшому буде називатися стабілізуючою платформою. Технічна досконалість систем стабілізації озброєння оцінюється показниками, що характеризують якість їі функціонування як у режимі стабілізації, так і в режимі наведення. Найбільш важливими з них $є$ :

- стійкість;

- точність стабілізації зброї (жорсткість);

- якість стабілізації;

- швидкість наведення і характер розподілу по куту повороту пульта управління;

- час готовності стабілізатора;

- час безперервної роботи стабілізатора, протягом якого технічні характеристики відповідають необхідним;

- н надійність функціонування;

- характер i час перехідних процесів при відпрацюванні великих кутів неузгодженості (демпфування).

Стійкість забезпечує основне призначення іï як системи автоматичного управління, що полягає у підтримці заданого постійного значення регульованого параметра або в його зміні за визначеним законом. При відхиленні регульованого параметра від заданої величини (наприклад, під дією збурення або зміни цілі) регулятор впливає на систему таким чином, щоб ліквідувати це відхилення. Якщо система в результаті цього впливу повертається у початковий стан або переходить в інший рівноважний стан, то така система називається стійкою. Якщо ж виникають коливання зі зростаючою амплітудою або відбувається монотонне збільшення помилки, то система називається нестійкою.

Точність стабілізації є основним показником, що характеризує роботу системи управління вогнем у режимі стабілізації. Зовнішні збурення, обумовлені безперервними випадковими коливаннями корпусу рухомою легкою броньованою технікою, викликають відхилення стабілізованого озброєння від заданого напрямку наведення.

Для кількісної оцінки точності стабілізації визначаються середні значення абсолютних кутових відхилень стабілізованого озброєння - середні значення похибок стабілізації. 
Як міра точності систем стабілізації озброєння використовуються:

- середня квадратична похибка;

- середня амплітудна.

Похибка стабілізації визначається експериментально за допомогою спеціальної апаратури i вимірюється в тисячних долях. Чим вища точність стабілізації, тобто чим менше відхилення зброї від заданого наведенням напрямку, тим вище якість стабілізатора і навпаки.

Сучасні системи стабілізації дозволяють отримати досить високі значення точності стабілізації зброї ( $\alpha=0,6-0,8$ тис.), що обумовлює високу ефективність стрільби з ходу.

Швидкість наведення стабілізованого об'єкта при наведенні або стеженні за ціллю характеризує якість системи в режимі наведення. Для здійснення точного наведення зброї на ціль виконавчі приводи стабілізатора мають забезпечувати обертання об'єкта регулювання з кутовими швидкостями, які плавно змінюються від значень 0,05-0,07 град./с до 5-6 град./с.

Залежність від кута повороту пульта управління в цьому діапазоні швидкостей наведення має бути лінійною (або близькою до неї) з градієнтом зміни кутової швидкості не більше 0,002 рад/с/град. Це необхідно для забезпечення можливості безперервного і точного стеження за рухомими цілями.

Для швидкого переміщення зброї при переведенні вогню по фронту з однієї цілі на іншу необхідно, щоб виконавчі приводи забезпечували їх обертання з кутовими швидкостями Qmax > 30-35 град./с.

Час готовності стабілізатора - інтервал часу від моменту ввімкнення стабілізатора до початку його працездатності - визначається тривалістю процесу розгону гіродвигунів. Для сучасної бойової машини час готовності - не більше 2 хв (у тому числі й час ввімкнення - не більше 20 с).

Час безперервної роботи стабілізатора визначається технічними умовами на підставі часу виконання бойових завдань підрозділом.

Жорсткість стабілізатора являє собою питомий стабілізуючий момент, що розвивається виконавчим приводом. Жорсткість залежить від величини передатного коефіцієнта сигналу датчика кутової швидкості та коефіцієнтів підсилення компонентів регулятора.

Різну роль у системах відтворення кута і стабілізації відіграє й момент тертя на виконавчій осі. У першому випадку момент тертя може сприяти демпфуванню коливань об'єкта, а в другому - він сам є причиною виникнення коливань об'єкта, оскільки тертя в опорах його підвісу захоплює стабілізуючий об'єкт. Абсолютно специфічною є динаміка систем гіроскопічної стабілізації, що побудована за силовою схемою, де момент гіроскопічної реакції безпосередньо використовується для компенсації збурюючих моментів, що діють на стабілізуючий об'єкт.

3 точки зору вимог до запасу стійкості немає ніяких відмінностей між спостережною системою відтворення кута і системою стабілізації. Це пояснюється тим, що умови стійкості визначаються рівняннями вільного руху системи, які однакові в обох випадках.

Збільшення необхідної точності системи стабілізації при збереженні їі структури призведе до збільшення необхідного коефіцієнта передачі розімкнутої системи, а отже, до зменшення іiі запасу стійкості. При синтезі системи методом логарифмічних амплітудних характеристик найбільш просто оцінювати ії̈ запас стійкості за показником коливальності.

Сьогодні є перспективними дослідження підвищення точності саме п'єзоелектричних чутливих елементів. Авторами статті розроблено новий прецизійний п'єзоелектричний чутливий елемент, який має вищу точність порівняно з відомими аналогами [13-14, 16].

Як бачимо, точність стабілізації сильно залежить від точності чутливих елементів системи стабілізації. Вихідні сигнали цих чутливих елементів містять значні похибки, описані в [1]. Найпоширенішим методом їх ліквідації $є$ використання фільтрів нижніх частот. Проте існують й інші методи фільтрації, які уникають необхідність використання фільтрів як окремих блоків конструкції системи стабілізації озброєння. Одним із них є метод двоканальності Петрова [15].

Одне 3 найголовніших питань теорії регулювання за збуренням $є$ питання реалізації умов інваріантності. Якщо застосування принципу регулювання за збуренням дає низку суттєвих переваг i дозволяє побудувати системи автоматичного регулювання, що характеризуються високою динамічною точністю і базуються на виконанні умов інваріантності, то головною задачею залишається реалізації цих умов у реальних системах автоматичного регулювання.

Найбільш суттєві результати розв'язання цієї задачі отримано в роботах Б.Н. Петрова [15].

Постановка задачі реалізації умов інваріантності полягає у тому, щоб вказати загальний «критерій, який дозволив би визначити необхідні умови можливості застосування умов інваріантності, як одного із методів розрахунку динамічних систем і виключати ті системи, для яких застосування даних умов $\epsilon$ недопустимим, тобто може призвести до фізично нездійсненних результатів».

Вирішення вказаної задачі сформульовано Б.Н. Петровим у вигляді такого критерію: «Необхідною (але не достатньою) ознакою можливості застосування умов інваріантності при розрахунку різних динамічних систем являється обов'язкова наявність в схемі, принаймні двох каналів впливу між точками прикладання сили збурення і виміру потрібної нам величини». 
На конкретних прикладах Б.Н. Петровим проілюстровано випадки систем, під час розрахунку яких можливо застосувати умови інваріантності, а також вказано протилежний клас систем. Одним 3 таких прикладів є система, що описується рівнянням [15]:

$$
\begin{aligned}
& a_{11} x_{1}+\ldots+a_{13} x_{3}=f_{1}(t) ; \\
& a_{31} x_{1}+a_{22} x_{2}+a_{23} x_{3}=0 ; \\
& a_{32} x_{2}+a_{33} x_{3}=0,
\end{aligned}
$$

і допускає у випадку, якщо вона впорядкована, зобразити її у структурній формі (рис. 1).
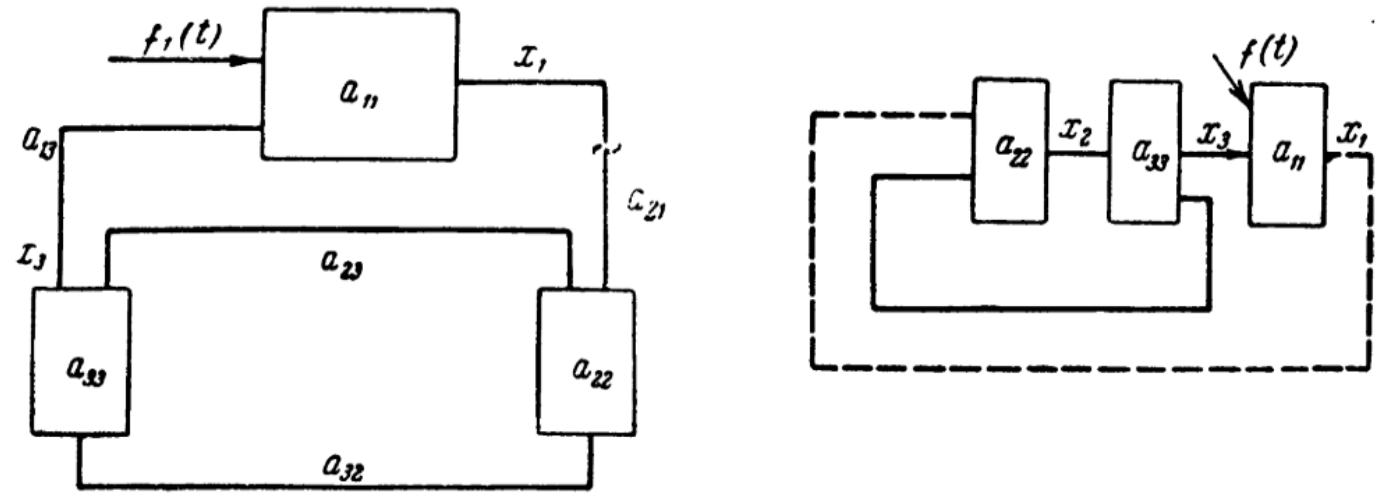

Рис. 1. Структурні перетворення схем

Візьмемо ту саму систему диференційних рівнянь, але поміняємо їх місцями, тобто напишемо у вигляді:

$$
\begin{aligned}
& a_{21} x_{1}+a_{23} x_{3}+a_{33} x_{3}=0 \\
& a_{32} x_{2}+a_{33} x_{3}=0 \\
& a_{11} x_{1}+a_{12} x_{3}+a_{13} x_{3}=f_{1}(t) .
\end{aligned}
$$

Структурна схема цієї системи у випадку ії̈ впорядкованості подана на рисунку 2.

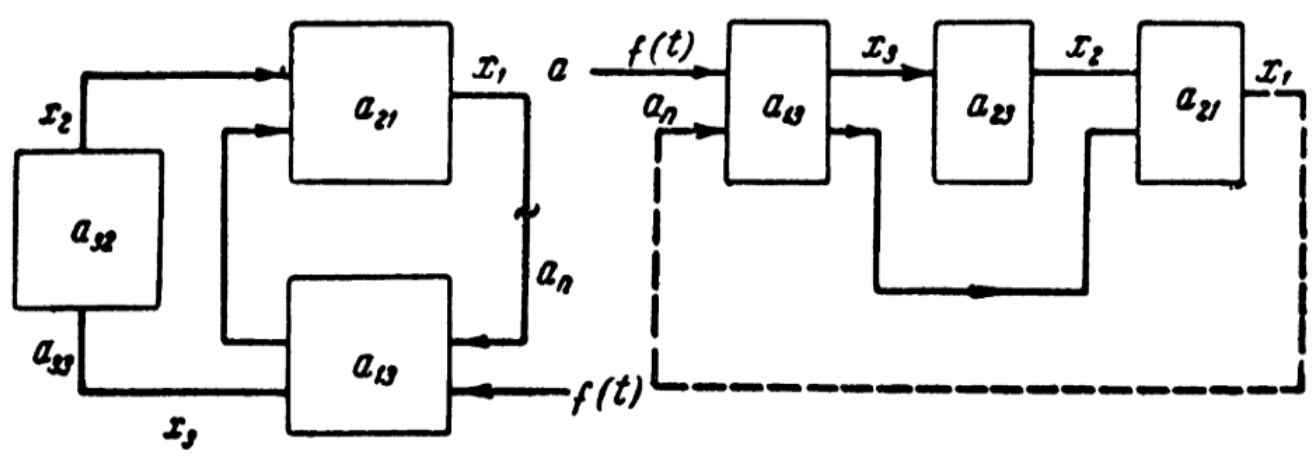

Рис. 2. Приклад структурного перетворення схеми

Перша система має лише один канал взаємодії між точкою прикладання збурення $f(t)$ та $x_{1}(t)$, а інша два канали для взаємодії між $f(t)$ та $x_{1}(t)$.

Згідно з критерієм Б.Н. Петрова перша система є такою, для якої умови інваріантності неприйнятні, і навпаки, у випадку другої системи (рис. 2) умови інваріантності мають фізичну реалізацію.

Слід також зауважити, що вказаний критерій дійсний для класу автономних систем, комбінованих систем, мостових схем тощо [15].

Підвищення точності вимірювання у новому чутливому елементі стабілізатора озброєння забезпечується за рахунок того, що створено другий канал вимірювання (за методом Петрова).

Для цього чутливий п’єзоелектричний елемент виконано з двома каналами. П'єзоелемент одного каналу, що встановлено інерційною масою на п'єзопластинах, працює на стиснення. Ідентичний йому п’єзоелемент іншого каналу, що встановлено інерційною масою під п'єзопластинами, працює на розтяг. Вихідні електричні сигнали п’єзопластин обох каналів сумуються у суматорі. Результуючий корисний електричний сигнал буде пропорційним подвоєному корисному сигналу.

Отже, завдяки використанню додатково введеного другого каналу вимірювання забезпечується відсутність у вихідному сигналі чутливого елемента сигналів похибок від впливу вертикального 
прискорення, від залишкової неідентичності конструкцій однакових п’єзопластин та мас, від впливу зміни температури, вологості та тиску зовнішнього середовища (тобто інструментальних похибок), які можуть бути значними. Суть методу пояснюється кресленням, де зображено структурну схему п'єзоелектричного чутливого елемента (рис. 3).

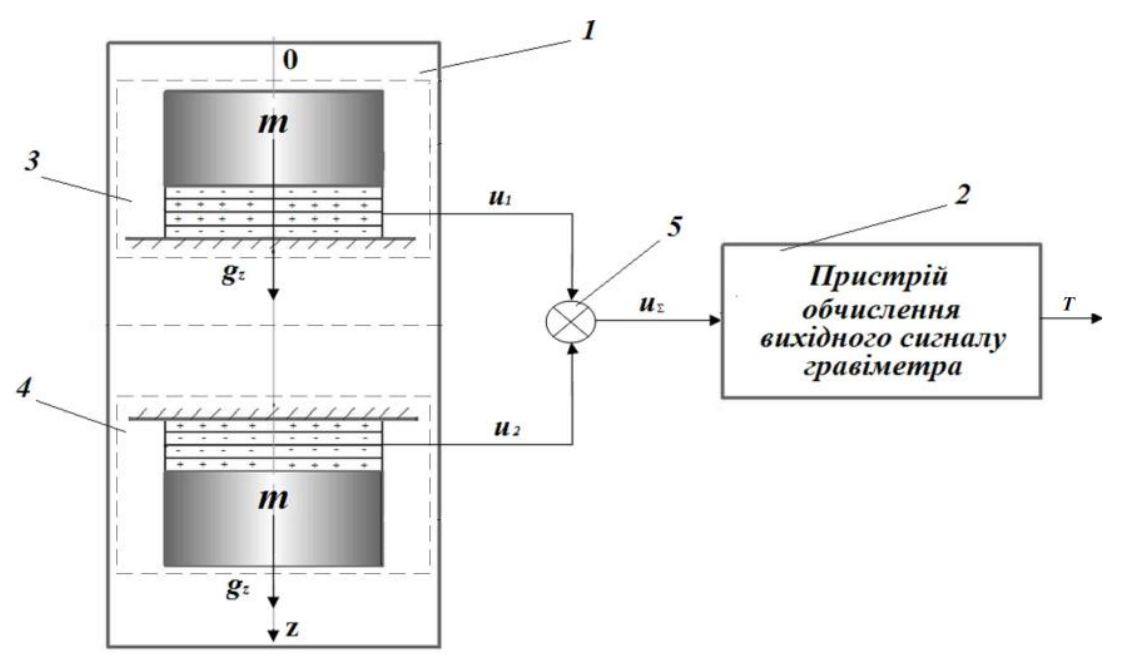

Рис. 3. Структурна схема двоканального п'єзоелектричного чутливого елемента

Чутливий елемент 1 виконано 3 двома каналами, в кожному 3 яких встановлено по одному п'єзоелементу. П'єзоелементи обох каналів є ідентичними і виконані у вигляді п'єзопластин та інерційної маси, що закріплені одне на одному. П'єзоелемент 3 одного каналу розташовано п'єзопластинами вниз, а п'єзоелемент 4 іншого каналу розташовано п'єзопластинами вгору. Виходи п'єзопластин обох каналів з'єднано з входами суматора 5, вихід якого з'єднаний із входом пристрою 2 обчислення вихідного сигналу гравіметра.

П'єзоелектричний чутливий елемент працює таким чином.

На п’єзоелементи обох каналів діє прискорення $g_{z}$, вертикальне прискорення $\Delta \ddot{z}$ та інструментальні похибки $\Delta i$ від впливу залишкової неідентичності конструкцій однакових п'єзопластин та мас, від впливу зміни температури, вологості та тиску зовнішнього середовища. Якщо спроєктувати всі ці впливи на вимірювальну вісь $O z$ нового чутливого елемента та врахувати те, що п'єзоелемент 3 одного каналу працює на стиснення, а п'єзоелемент 4 іншого каналу - на розтяг, то отримаємо [28-32]:

$$
\begin{aligned}
& u_{1}=k\left(m g_{z}+m \Delta \ddot{z}+\Delta i\right) ; \\
& u_{2}=k\left(m g_{z}-m \Delta \ddot{z}-\Delta i\right),
\end{aligned}
$$

де $u_{1}$ - вихідний електричний сигнал п'єзопластин одного каналу;

$u_{2}$ - вихідний електричний сигнал п'єзопластин іншого каналу;

$m$ - вага інерційної маси у кожному каналі;

$k$ - п'єзоелектрична стала.

Вихідні електричні сигнали $u_{1}$ та $u_{2}$ п'єзопластин обох каналів сумуються у суматорі 5:

$$
u_{\Sigma}=u_{1}+u_{2}=2 k m g_{z},
$$

де $u_{\Sigma}-$ вихідний сигнал суматора 5.

Вихідний сигнал $u_{\Sigma}$ суматора 5 подається у пристрій 2 обчислення вихідного сигналу гравіметра, де він обчислюється за певний інтервал часу. У кінцевому результаті отримуємо вихідний сигнал $T$ пристрою 2 обчислення вихідного сигналу чутливого елемента, який містить подвоєний корисний сигнал. У ньому повністю відсутні такі похибки вимірювань, які спричинені впливом вертикального прискорення $\Delta \ddot{z}$ та інструментальних похибок $\Delta i$.

Висновки та перспективи подальших досліджень. Розглянуто будову системи стабілізації озброєння. Встановлено параметри, від яких залежить якість функціонування систем стабілізації озброєння як в режимі стабілізації, так і в режимі наведення. Розглянуто новий п'єзоелектричний чутливий елемент системи стабілізації озброєння та доцільність використання методу двоканальності для підвищення його точності. У перспективі доцільно розглянути можливість використання нейромережевого підходу та вейвлет-аналізу у задачах розробки алгоритмів функціонування i комплексування чутливих елементів з метою значного зменшення впливу інструментальних похибок. 
Список використаної літератури:

1. Безвесільна О.М. Система захисту приладового комплексу від ударних та вібраційних впливів : монографія 3 грифом НТУУ «КПІ ім. Ігоря Сікорського» / О.М. Безвесільна, А.Г. Ткачук. - Київ : НПО «Пріоритети», 2018. $-170 \mathrm{c}$.

2. Тарасенко А. Бронетанковая техника Украины: итоги, потенциал, перспективы / А.Тарасенко // Техника и Вооружение. - 2008. - № 4. - C. 29-35 [Електронний ресурс]. - Режим доступу : http://militaryarticle.ru/tekhnika-i-vooruzhenie/2008/11678-bronetankovaja-tehnika-ukrainy-2.

3. Базіло К.В. Схемотехнічне моделювання п'єзоелектричного перетворювача 3 додатковими коливальними контурами / К.В. Базіло // Вісник Хмельницького національного університету. - 2013. - № 6. - С. 166-169.

4. Кузнєцов Б.І. Система наведення і стабілізації озброєння легкоброньованих машин 3 нейромережевим регулятором / Б.І. Кузнєцов, Т.Ю. Василець, О.О. Варфоломієв // Системи озброєння і військова техніка. 2010. - № 1 (13). - C. 112-116.

5. Chikovani V.V. Influence of shock on the vibration amplitude stabilization system of Coriolis vibratory gyroscope resonator / V.V. Chikovani // Електроніка та системи управління. - 2012. - № 4 (34). - C. 56-63.

6. Quartz structures for Coriolis Vibrating Gyroscopes / J.Guerard, D.Janiaud, R.Taibi, R.Levy // Phys. \& Instrum. Dept. - France, Chatillon : ONERA, 2014. - P. 1-4.

7. Remillieux G. Sagem Coriolis Vibrating Gyros: A vision realized / G.Remillieux, F.Delhaye // Inertial Sensors and Systems Symposium (ISS). - 2014. - P. 1-13.

8. Маляров С.П. Система стабилизации амплитуды колебаний резонатора кориолисового вибрационного гироскопа / С.П. Маляров, Ю.В. Кохан, В.В. Чиковани // Вісник інженерної академії України. - № 1. 2013. - C. 20-25.

9. ЦЦірук В.Г. Система ударо- і віброзахисту навігаційного комплексу легкої броньованої техніки / В.Г. Цірук // Технологічні комплекси. - 2014. - № 2 (10). - С. 134-141.

10. Development of a gyro stabilization system with fiber-optic gyroscopes for an air-sea gravimeter / A.V. Sokolov, A.A. Krasnov, L.P. Starosel'tsev, A.N. Dzyuba // Gyroscopy Navig. - 2015. - № 6. - P. 338-343.

11. Time stability of spring and superconducting gravimeters through the analysis of very long gravity records / M.Calvo, J.Hinderer, S.Rosat and other // Journal of Geodynamics. - 2017. - № 106. - P. 30-32.

12. Integration of a Strapdown Gravimeter System in AN Autonomous Underwater Vehicle / C.Roussel, J.Verdun, J.Cali, M.Maia // International Archives of the Photogrammetry, Remote Sensing and Spatial Information Sciences. - 2015. - Vol. XL-5/W5. - P. 199-206.

13. Piezoelectric Gravimeter of the Aviation Gravimetric System / O.Bezvesilna, I.Korobiichuk, A.Tkachuk and other // Advances in Intelligent Systems and Computing. - 2016. - № 440. - P. 753-761.

14. Design of piezoelectric gravimeter for automated aviation gravimetric system / O.Bezvesilna, I.Korobiichuk, A.Tkachuk and other // Journal of Automation, Mobile Robotics \& Intelligent Systems. - 2016. - Vol. 10, Issue 1. P. 43-47.

15. Уланов Г.М. Регулирование по возмущению. Компенсация возмущений и инвариантность : научное пособие / Г.М. Уланов. - М. : Государственное энергетическое издательство, 1960. - 110 с.

16. Патент України на винахід № 113033. Трикоординатний п’єзоелектричний гравіметр авіаційної гравіметричної системи / О.М. Безвесільна, А.Г. Ткачук, Т.В. Хильченко, Р.В. Бичук. - № а2015 09858 ; заявл. 12.10.2015 ; опубл. 25.11.2016 ; Бюл. № 22/2016.

\section{References:}

1. Bezvesilna, O.M. and Tkachuk, A.H. (2018), Systema zahystu pryladovogo kompleksu vid udarnyh ta vibracijnyh vplyviv , monografija z gryfom NTUU «KPI im. Igorja Sikors'kogo», NPO «Priorytety», Kyi'v, 170 p.

2. Tarasenko, A. (2008), «Bronetankovaya tehnika Ukrainyi: itogi, potentsial, perspektivyi», Tehnika i Vooruzhenie, No. 4, pp. 29-35, [Online], available at: http://militaryarticle.ru/tekhnika-i-vooruzhenie/2008/11678bronetankovaja-tehnika-ukrainy-2

3. Bazilo, K.V. (2013), «Shemotehnichne modeljuvannja p'jezoelektrychnogo peretvorjuvacha z dodatkovymy kolyval'nymy konturamy», Visnyk Hmel'nyc'kogo nacional'nogo universytetu, No. 6, pp. 166-169.

4. Kuznjecov, B.I., Vasylec', T.Ju. and Varfolomijev, O.O. (2010), «Systema navedennja i stabilizacii' ozbrojennja legkobron'ovanyh mashyn z nejromerezhevym reguljatorom», Systemy ozbrojennja i vijs'kova tehnika, No. 1 (13), pp. 112-116.

5. Chikovani, V.V. (2012), «Influence of shock on the vibration amplitude stabilization system of Coriolis vibratory gyroscope resonator», Elektronika ta systemy upravlinnja, No. 4 (34), pp. 56-63.

6. Guerard, J., Janiaud, D., Taibi, R and Levy, R. (2014), «Quartz structures for Coriolis Vibrating Gyroscopes», Phys. \& Instrum. Dept., ONERA, Chatillon, France, pp. 1-4.

7. Remillieux, G. and Delhaye, F. (2014), «Sagem Coriolis Vibrating Gyros: A vision realized», Inertial Sensors and Systems Symposium (ISS), pp. 1-13.

8. Maljarov, S.P., Kohan, Ju.V. and Chikovani, V.V. (2013), «Sistema stabylyzacyi amplytudy kolebanija rezonatora koriolisovogo vibracyonnogo giroskopa», Visnyk inzhenernoi' akademii' Ukrai'ny, No. 1, pp. 20-25.

9. Ciruk, V.G. (2014), «Systema udaro- i vibrozahystu navigacijnogo kompleksu legkoi' bron'ovanoi' tehniky», Tehnologichni kompleksy, No. 2 (10), pp. 134-141.

10. Sokolov, A.V., Krasnov, A.A., Starosel'tsev, L.P. and Dzyuba, A.N. (2015), «Development of a gyro stabilization system with fiber-optic gyroscopes for an air-sea gravimeter», Gyroscopy Navig, No. 6, pp. 338-343.

11. Calvo, M., Hinderer, J., Rosat, S. and other (2017), «Time stability of spring and superconducting gravimeters through the analysis of very long gravity records», Journal of Geodynamics, No. 106, pp. 30-32. 
12. Roussel, C., Verdun, J., Cali, J. and Maia, M. (2015), «Integration of a Strapdown Gravimeter System in AN Autonomous Underwater Vehicle», International Archives of the Photogrammetry, Remote Sensing and Spatial Information Sciences, Vol. XL-5/W5, pp. 199-206.

13. Bezvesilna, O., Korobiichuk, I., Tkachuk, A. and other (2016), «Piezoelectric Gravimeter of the Aviation Gravimetric System», Advances in Intelligent Systems and Computing, No. 440, pp. 753-761.

14. Bezvesilna, O., Korobiichuk, I., Tkachuk, A. and other (2016), «Design of piezoelectric gravimeter for automated aviation gravimetric system», Journal of Automation, Mobile Robotics \& Intelligent Systems, Vol. 10, Issue 1, pp. 43-47.

15. Ulanov, G.M. (1960), Regulirovanie po vozmushheniju. Kompensacija vozmushhenij i invariantnost', nauchnoe posobie, Gosudarstvennoe jenergeticheskoe izdatel'stvo, M., $110 \mathrm{p}$.

16. Bezvesilna, O.M., Tkachuk, A.H., Hyl'chenko, T.V. and Bychuk, R.V. (2016), Trykoordynatnyj p'jezoelektrychnyj gravimetr aviacijnoi' gravimetrychnoi' systemy, Ukrai'na, Patent na vynahid № 113033.

Безвесільна Олена Миколаївна - доктор технічних наук, професор, професор кафедри приладобудування Національного технічного університету «Київський політехнічний інститут імені Ігоря Сікорського».

Наукові інтереси: об’єктів;

- фундаментальні та прикладні питання механіки гіроскопічних і навігаційних приладів рухомих

- розробка методів і комп'ютерних технологій обробки вимірювальної інформації навігаційного комплексу;

- створення нового автоматизованого прецизійного кутомірного засобу для попередньої виставки навігаційних елементів;

- стабілізатори озброєння легкої броньованої техніки.

https://orcid.org/0000-0002-6951-1242.

Ткачук Андрій Геннадійович - кандидат технічних наук, доцент, завідувач кафедри автоматизації та комп'ютерно-інтегрованих технологій імені проф. Б.Б. Самотокіна Державного університету «Житомирська політехніка».

Наукові інтереси:

- автоматизовані авіаційні гравіметричні системи;

- п’єзоелектричні чутливі елементи;

- сучасні інформаційно-вимірювальні системи;

- стабілізатори озброєння легкої броньованої техніки.

https://orcid.org/0000-0003-2466-6299.

Гуменюк Анна Анатоліївна - кандидат технічних наук, доцент, доцент кафедри автоматизації та комп'ютерно-інтегрованих технологій імені проф. Б.Б. Самотокіна Державного університету «Житомирська політехніка».

Наукові інтереси:

- автоматизовані вимірювальні системи;

- гравіметрія;

- автоматизація проєктування гнучких виробничих систем.

http://orcid.org/0000-0002-5744-4599.

Янчук Валентин Миколайович - кандидат технічних наук, доцент, доцент кафедри автоматизації та комп'ютерно-інтегрованих технологій імені проф. Б.Б. Самотокіна Державного університету «Житомирська політехніка».

Наукові інтереси:

- математичне моделювання технологічних процесів;

- розробка програмного забезпечення;

- підтримка систем електронної комерції.

https://orcid.org/0000-0002-6715-4667.

Добржанський Олександр Олексійович - кандидат технічних наук, доцент, доцент кафедри автоматизації та комп'ютерно-інтегрованих технологій імені проф. Б.Б. Самотокіна Державного університету «Житомирська політехніка».

Наукові інтереси:

- сучасні інформаційно-вимірювальні системи;

- розробка програмного забезпечення.

https://orcid.org/0000-0002-4330-0287. 